\title{
THE POSSIBLE USE OF ANCIENT TOWER TOMBS AS WATCHTOWERS IN SYRO-MESOPOTAMIA
}

\section{New Aspects Achieved from Locational Information and Viewshed Analyses}

\author{
Minna Silver ${ }^{\mathrm{a}}$, Markus Törmä ${ }^{\mathrm{b}}$, Kenneth Silver $^{\mathrm{c}}$, Jari Okkonen $^{\mathrm{d}}$, Milton Nuñez $^{\mathrm{e}}$ \\ a Department of Archaeology, Mardin Artuklu University, 74200 Mardin, Turkey - minnaangelina@artuklu.edu.tr \\ baalto University, Espoo, Finland - markus.torma@aalto.fi \\ ${ }^{c}$ Independent researcher - klonnqvi@hotmail.co.uk \\ ${ }^{\mathrm{d}}$ University of Oulu, Oulu, Finland - jari.okkonen@ oulu.fi \\ ${ }^{\mathrm{e}}$ University of Oulu, Oulu, Finland - milton.nunez@oulu.fi
}

KEYWORDS: Archaeology, Remote Sensing, GIS, Topography, Spatial Information, Cultural Heritage, World Heritage Sites

\begin{abstract}
:
Traditionally polygonal tower tombs dating from the Greco-Roman era, especially found in the area of Syro-Mesopotamia, have only been treated as funerary structures without discussion of their other possible purposes. In this paper we wish to inquire whether they had other functions as well. The most famous examples of these types of tombs are situated in Palmyra in Syria. They are built of limestone, follow a square layout, and some exceed the height of $20 \mathrm{~m}$. Similar structures are found in the Euphrates valley of Syria. The Finnish project SYGIS that worked in the neighbourhood of the Euphrates and Palmyra during the previous decade studied some of the structures in the region. As far as the tower tombs are concerned, our research suggests that new structural, topographical and spatial aspects can be raised, and GIS (Geographic Information Systems) can be applied for analysing their properties for visibility. The tendency to locate tower tombs along roads and the entrance areas of a city as well as at a mountain edge seems to indicate that the tombs may have had observational functions serving as watch towers. The aspects of the location in terrains are emphasized in the present study, and digital terrain models were utilized using SRTM DEM (Digital Elevation Model) data for carrying out viewshed analyses in order to survey the observational qualities of the towers in Palmyra, on Halabiya, on Jebel Bishri in Syria and Hatra in Iraq.
\end{abstract}

\section{INTRODUCTION}

\subsection{Polygonal Tower Tombs: Structures and their Distribution}

Tower tombs represent a particular type of funerary structures that are especially known to have been preferred in Palmyra in Syria during the Greco-Roman period, from the $1^{\text {st }}$ century BC to the $2^{\text {nd }}$ century $\mathrm{AD}$ (see, e.g., Henning, 2013). That was the heyday of this caravan city on the Silk Road situated in an oasis in the midst of a desert (Gawlikowski, 1996, Stoneman, 1992).

The stone built tower tombs that are visible today in Palmyra, especially in the Valley of Tombs, have a square layout and follow the Hellenistic architectural idealism of polygonal towers but applying Iranian, especially Parthian, taste into their architecture. In this paper we only deal with the tower tombs that are rectangular in plan. Most of them are in a ruined state. But there are well-preserved examples, too. Those structures in Palmyra include several stories, and winding staircases are running between the stories. The original height may even exceed 20 meters, as there are intact examples that have been measured. The deceased were buried in loculi in successive stories and/or subterranean hypogea. (Brall et al., 2001).

The ruins of similar square towers are known on the Euphrates on the peninsula of Halabiya associated with the fortress city of Zenobia, possibly at the fort of Tabus on Jebel Bishri, at the fortress city of Dura Europos and at Baghouz in SyroMesopotamia (see Will, 1949b). The dates of the sites vary from the Hellenistic to Roman and Byzantine periods. A comparable tower tomb is also known from Edessa-Urfa (Drijvers, 1980) in Turkey, and such have been inserted into the walls of Hatra in

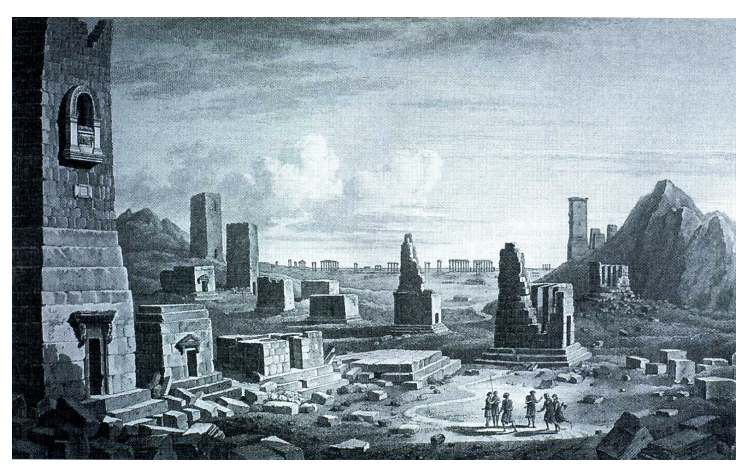

Figure 1 . An old $18^{\text {th }}$ century drawing by F. Cassas depicting the Valley of Tombs in Palmyra in Syria.

Iraq as well (Metzger, 1998). Both of the sites are situated also in Mesopotamia. Of all the examples of the tombs, the best preserved ones are in Palmyra, and altogether ca. 180 towers and their ruined remains are known there (Henning, 2013).

Square towers became popular architectural designs used in defensive constructions and ritual monuments in the Hellenistic world along Alexander the Great's conquests and journeys. During the Greco-Roman period temples dedicated to solar and astral cults such as the Temple of Jupiter in Baalbek in Lebanon and Temple of Bel in Palmyra in Syria comprised stepped towers for observation. R. Amy suggests that their origin is to be sought in Iran (Amy, 1950, Browning, 1979). The sites of caravan cities of Hatra, Palmyra and Petra dating from the Roman period, however follow Parthian ideals adapted into the Greco-Roman art and architecture (see Rostovtzeff, 1932, Anadol, 2008). Some tomb façades in Petra in Jordan provide 
tower-like designs that clearly bear features of an Iranian impact. The rock-cut tombs in the necropolis of the Kidron Valley in Jerusalem in Israel dating from the Hellenistic and Roman times have some common features as well (see Avigad, 1976).

Here we wish to take our previous studies further and inquire whether there were multiple functions for tower tombs, because the preliminary observations of their structures and locations in terrain indicate to their use as watchtowers as well. Watchtowers are known to be structures that provide elevated observation points for a viewer. Therefore we decided to provide digital elevation data (DEM) and apply GIS (Geographic Information Systems) to carry out viewshed analyses based on the locations of the tombs in their terrains (see Wheatley 1995, Wheatley and Gillings, 2000) and study their qualities for surveillance. Viewshed analyses have been used in studying territorial, political, ethnic and religious questions. They have employed the benefits of topographic maps and digital elevation models (DEM).

For caravan cities, if placed in convenient locations, the tower tombs may have offered an opportunity for observations and to follow the movement of the caravans, but they also could have been used for strategic aims. In addition, because of the astral religions in the region at that time, the tombs as towers and ritual monuments may have been used for star gazing as well.

\subsection{Documenting Tower Tombs}

The tower tombs of Palmyra that are the most famous ones are standing at the SW entrance to the ancient city. Travellers since the Renaissance times have described them and drawn them. (Browning, 1979). From the ancient illustrations we can still trace sculptured decorations on the façades of the tombs. (Figs. 1. and 2.). From the beginning of the $20^{\text {th }}$ century there have been systematic studies of these structures (see the literature in Will, 1949a). More recently French, Syrian, Austrian, Polish and German archaeologists have drawn plans and studied these tombs. The sizes of the plan may vary from $11 \mathrm{~m}$ to $5 \mathrm{~m}$ a side (Will, 1949a), but the base of Elahbel's tomb reaches over $13 \mathrm{~m}$ a side (see Brall et al, 2001).

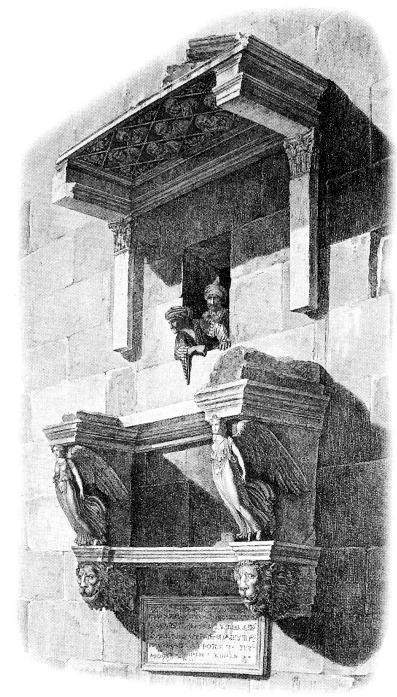

Figure 2. A $18^{\text {th }}$ century drawing of a window balcony with architectural decorations in the Tomb of Jamblique in Palmyra by F. Cassas.
Aerial reconnaissance of the tower tombs has also been carried out by the French in the 1920s and 1930s (Poidebard, 1934). Photogrammetric studies have been executed by Germans in Palmyra (Brall et al., 2001) and Italians such as G. Fangi and M. Franca (Fig. 3.) during the past decades. We are fortunate to have their precise documentation for the preservation of these monuments, especially the tomb of the Elahbel family that has been described and documented by early travellers and archaeologists.

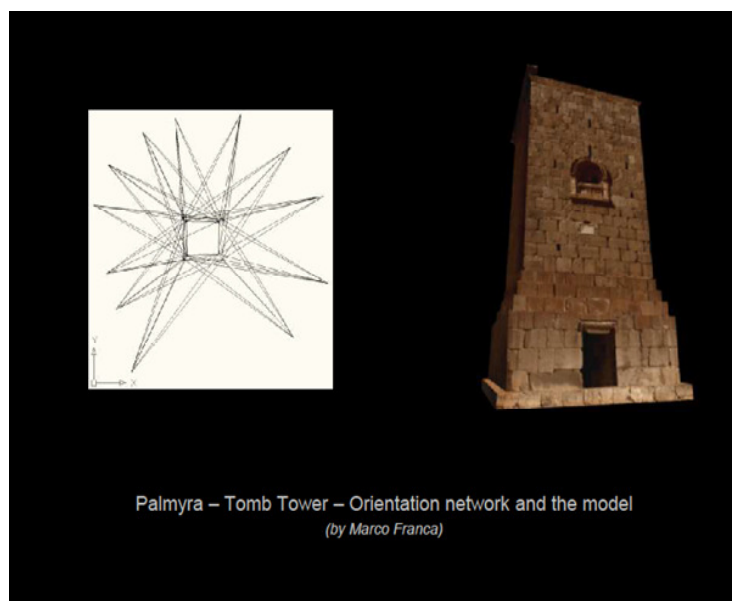

Figure 3. The Tower Tomb of Elahbel modelled by an Italian team led by G. Fangi. Courtesy G. Fangi.

Surveys and excavations have documented other tower tombs on the Euphrates. Already F. Sarre and E. Herzfeld $(1911,1920)$ recorded such on the Euphrates, and the French continued the work. The Finnish archaeological project SYGIS that worked during the previous decade in Syria was also able to observe the structures of some tower tombs in Palmyra and document as well as study similar structures at Tabus on Jebel Bishri. In addition, the project members observed some comparable structures on the peninsula of Halabiya before the break of the civil war in Syria.

The towers that are interpreted as tower tombs in previous studies (H 21, H 23) are situated some hundred meters from the Late Roman-Byzantine fort of Tabus. They are built of gypseous stones, but they may just consist of the remnants of a rubble core. The plan of Tower $\mathrm{H} 21$ covers $4 \mathrm{~m} \times 5 \mathrm{~m}$, and its preserved height is ca. $5 \mathrm{~m}$. The plan of the tower $\mathrm{H} 23$ covers $1.15 \mathrm{~m} \times 1.25 \mathrm{~m}$. (Lönnqvist et al., 2005, 2011, 319). The corner pilasters were still visible on Tower H 21 (Fig. 4.) to argue for its funerary use. This view is based on the comparisons with other tower tombs already made by F. Sarre and E. Herzfeld (1911), who dated one of the tower of Tabus to the third century AD. However, no funerary remains have been found in these towers so far, but there are visible robbers' attempts to destroy the monuments.

American excavations have documented tower tombs at Dura Europos, a fortress city on the Euphrates. They were found in the necropolis near the western wall of the city. Generally only stepped foundations of these towers were revealed under the stone and sand rubble, but one of them had two relief pilasters between corner pilasters (Toll, 1952). One of the tombs was dated to the first century BC (Will, 1949a). Scholars have expressed opinions about the differences of these tower tombs compared with those of Palmyra, and they have seen more similarities to those of Irzi and Halabiya (Rostovtzeff, 1937). 


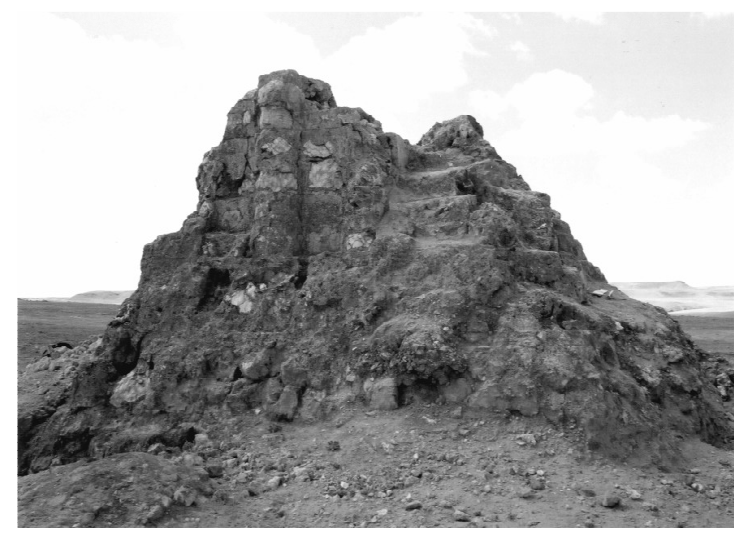

Figure 4. The ruined Tower H 21 at Tabus on Jebel Bishri. Photo from W: E. Seland 2004.

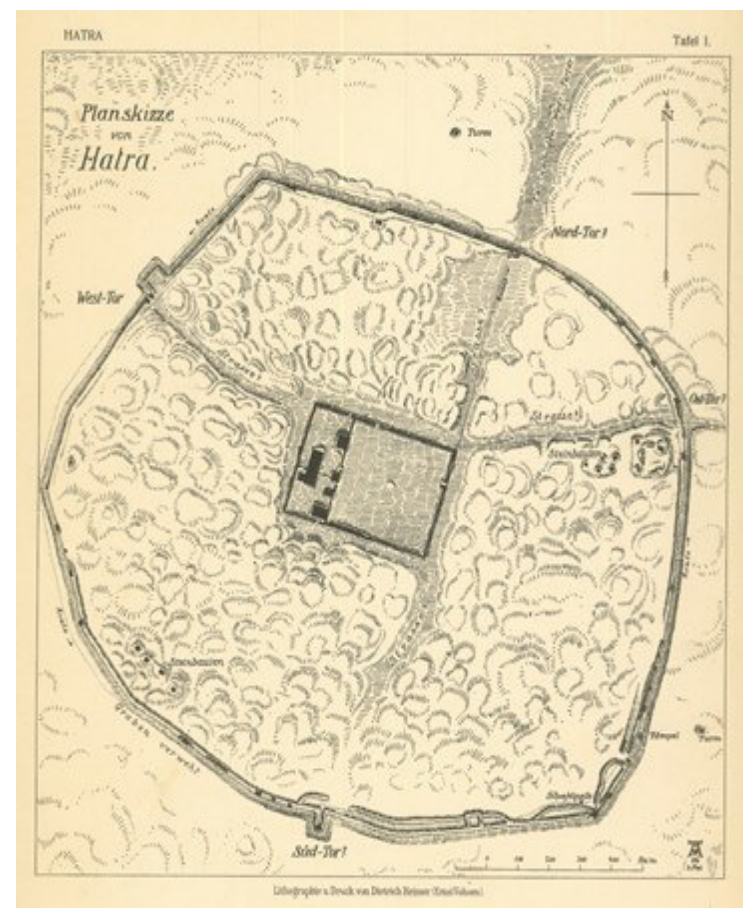

Figure 5. The circular plan of Hatra.

We never visited Hatra, but the reports provide information that there are tower tombs inserted in the existing ancient city walls. Hatra is one of the caravan cities, but unlike others it has a circular plan (Fig. 5.), and the walls surrounding are over $2 \mathrm{~km}$ long. After W. Andrae's studies in Hatra at the beginning of the $20^{\text {th }}$ century, the Iraqi and Polish excavations have been carried out at the site (Metzger, 1998). Italians, such as E. Foietta, have been GIS mapping the ruins producing 3D models, and some documentation has also been done by CyArk.

Generally the funerary buildings in Hatra have a square plan, either as freestanding structures or as inserted into the walls. There are ca. 142 funerary buildings, but the nature of some is not certain as no deceased have been found in them. Those inserted into the wall are built of mudbrick and standing on a stone foundation. Terminus ante quem $\mathrm{AD} 151$ for these structures has been provided, some dating to ca. AD 100 (Tomb J3 dated to either AD 108 and 111) (Metzger, 1998).

\section{THE LOCATIONS OF TOWER TOMBS IN TERRAINS}

\subsection{Aerial Reconnaissance and Visibilities}

As previously mentioned, the tower tombs of Palmyra have been documented by remote sensing already in the 1920s and 1930s by aerial photographing and mapping of the Roman Eastern frontier zone by A. Poidebard (Poidebard, 1934). (Figs. 6. and 7.). These aerial photographs and mappings are a valuable source for studying the terrain and the location of tower tombs in Palmyra. Satellite imagery can be added for the studies as we have done using Landsat images in observing the neighbourhood of Palmyra and its roads (see Fig. 8., and another article Silver et al., forthcoming in CIPA 2015).

Initially it was observed by the authors of the present paper that in Palmyra the staircases in some tower tombs offered entrances to window balconies and roofs on which surrounding areas were able to be observed (see Fig. 2.). Then it was noticed that the tombs were located into the entrance area, whence the road led in and out of the city in its SW part (see, e.g., Seland, 2008). As stated, for a caravan city such opportunities for the surveillance of the road traffic could have been applied in the case of the tower tombs.

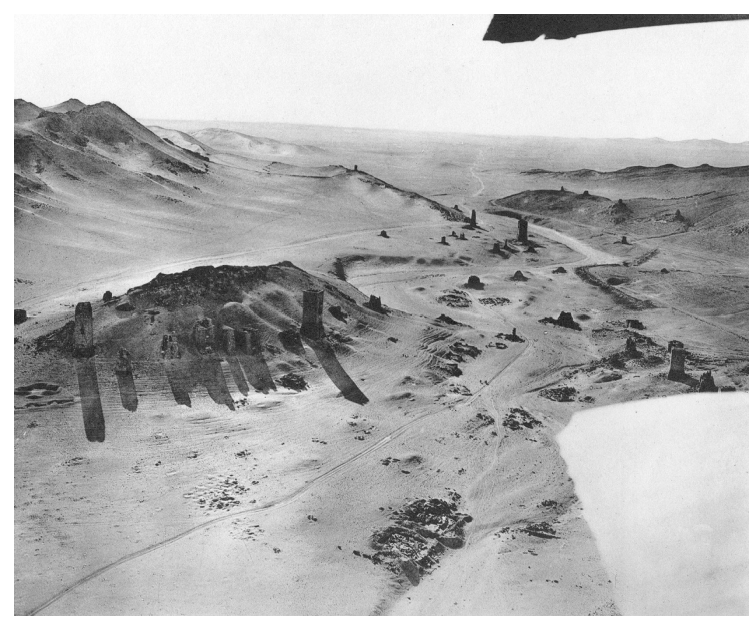

Figure 6. Father A. Poidebard's aerial photograph of the valley of tower tombs in Palmyra in Syria (Poidebard 1934).

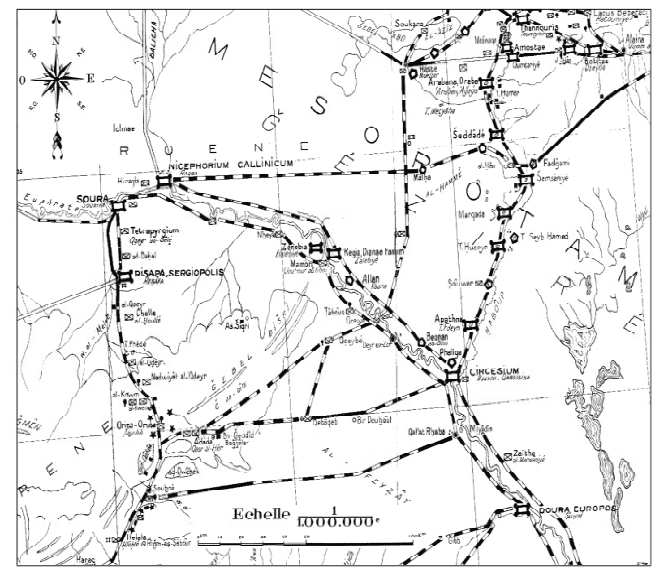

Figure 7. Part of Poidebard's map (1934) of the Roman eastern frontier zone in Syria displaying sites, such as cities, forts and fortresses in Syria. 
We were able to carry out spatial observations of the locations of tower tombs in situ in Palmyra, at the fort of Tabus on the northeastern mountain edge of Jebel Bishri and at the fortress of Zenobia on the peninsula of Halabiya on the Euphrates in between 1997 and 2009. During the studies of Tabus at the edge of Jebel Bishri, we especially paid attention to the location of the fort towers in the terrain and landscape in 2004-2005. We carried out viewshed analyses from Tabus to the neighbouring forts and fortresses and surrounding areas. (Lönnqvist et al., 2005).

Because of the locations of the apparent tower tombs at Tabus (H 21, H 23) standing separately from the fort above the Euphrates (Fig. 9.), we already suggested that the towers had apparently been used as watchtowers (Lönnqvist et al., 2005, 2011). Our views were based on the observation of the strategic position of the towers applying GIS (Geographic Information Systems) in the landscape location. The location provided the view over the Euphrates valley that was a border between Rome and Parthia (see Edwell, 2007) and also a site for guarding the entrance way to the fort.

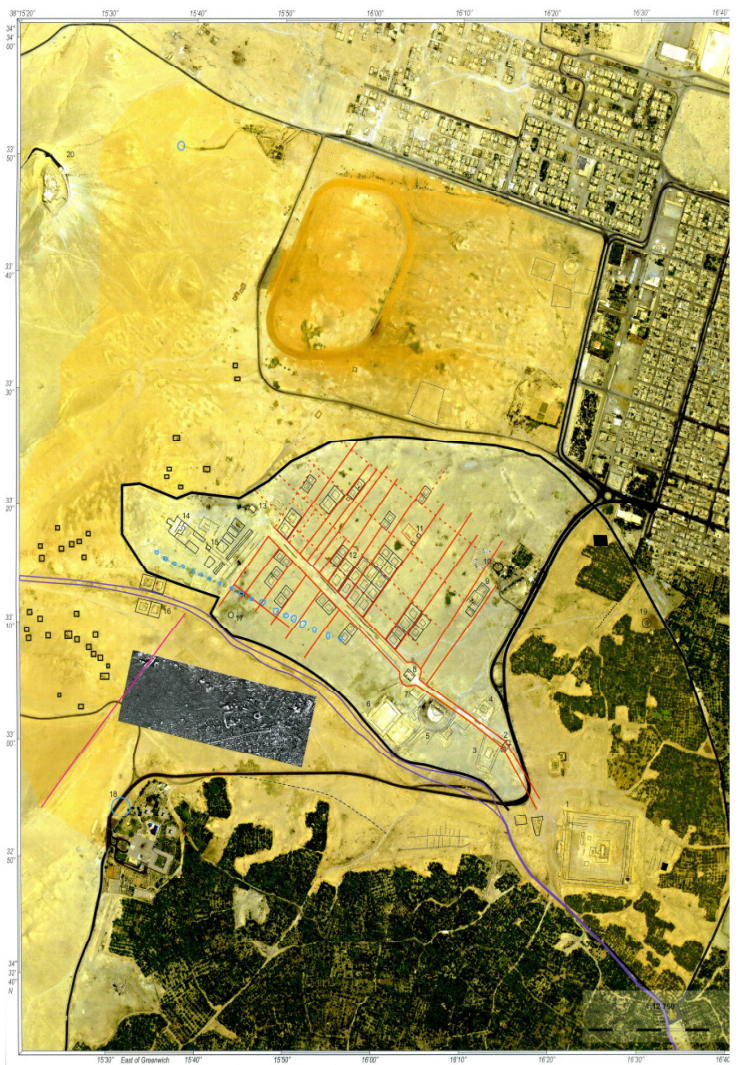

Figure 8. A satellite map of Palmyra. The tower tombs are visible to the left as small black squares. Courtesy: GORS, Damascus

Such strategic function had already been identified with the eastern tower of the fort over a road following the bank of the Euphrates (Lönnqvist et al., 2005). The same applies to the two ruined tower tombs that we observed in 2008 and 2009 along the entrance road to the fortress of Zenobia on Halabiya, only ca. $25 \mathrm{~km} \mathrm{NW}$ from Tabus. They had been constructed along the road leading to the fortress.

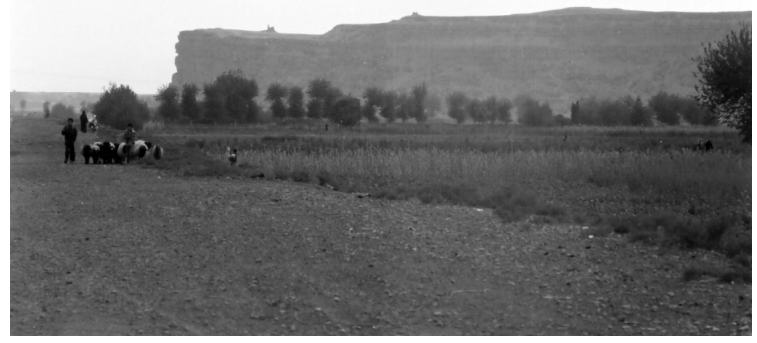

Figure 9. The visible ruins of tower tombs and towers of the fort at Tabus seen in silhouette at the edge of Jebel Bishri. Photo from NE: M. Lönnqvist 2009.

The excavators of Dura Europos suggest that the tendency was to make an imposing impression with the tower tombs in the landscape by constructing them further from the city walls on the main road in the plateau west of the city. The northern towers were presumably older than the southern ones. (Toll, 1952). During our visits to Dura Europos, we did not have opportunity to closely observe the tower tombs in its necropolis, but here again the tombs are located in the entrance area of the city or fortress, outside its walls and gates like in Palmyra, Tabus and Halabiya. This seems also to be the case of the tower tomb near Edessa-Urfa in Turkish Mesopotamia.

Hatra is an abandoned and ruined city like Dura Europos. Both of them have been already studied from the air early in the 20th century like Palmyra: Hatra was documented by Sir Aurel Stein and Dura by Father A. Poidebard in the early $20^{\text {th }}$ century. Nowadays satellite imagery has provided additional means to approach the ruins. The defensive purpose of some of the tower tombs was already noted by the early studies by W. Andrae at Hatra. These tombs are not connected to the necropolis. (Metzger, 1998).

The references of the defensive nature by Andrae are noteworthy, if we think about the other tower tombs, their connection with the Parthian culture and the caravan cities in general. As we have suggested, some strategic use for the towers in Syria can be assumed, the defensive wall actually reinforces this additional functional aspect of the free-standing tower tombs at the entrances of the cities and fortresses, as well as at the mountain edge. L. Dirven (2013) has recently noted that the existence of Palmyrenes in Hatra was not substantial, like in Dura Europos, though the connections were lively.

\section{VIEWSHED ANALYSES FROM THE SITES OF TOWER TOMBS}

\subsection{Capturing the Site Data}

The use of GoogleEarth satellite imagery was applied for further studies of the locations and capturing the site coordinates for the tower tombs in Palmyra, Tabus, Halabiya and Hatra. Fortunately GoogleEarth provides a tool to collect coordinates in the war struck zones, which we could not visit in 2015. See Table 1. But for Tabus we had earlier recorded UTM coordinates during our fieldwork (see Lönnqvist et al., 2011). 


\begin{tabular}{|l|l|}
\hline Site & Coordinates \\
\hline Palmyra1 & $34^{\circ} 33^{\prime} 5.99^{\prime \prime N}, 38^{\circ} 15^{\prime} 0.48^{\prime \prime} \mathrm{E}$ \\
\hline Palmyra2 & $34^{\circ} 33^{\prime} 15.98^{\prime \prime} \mathrm{N}, 38^{\circ} 15^{\prime} 17.22^{\prime \prime} \mathrm{E}$ \\
\hline J. Bishri & $35^{\circ} 28^{\prime} 11.34^{\prime \prime} \mathrm{N}, 39^{\circ} 57^{\prime} 22.82^{\prime \prime} \mathrm{E}$ \\
\hline Halabiya & $35^{\circ} 41^{\prime} 4.20^{\prime \prime} \mathrm{N}, 39^{\circ} 49^{\prime} 25.57^{\prime \prime} \mathrm{E}$ \\
\hline Hatra & $35^{\circ} 35^{\prime} 17.016^{\prime \prime} \mathrm{N}, 42^{\circ} 43^{\prime} 5.988^{\prime \prime} \mathrm{E}$ \\
\hline
\end{tabular}

Table 1.

\subsection{Viewshed Analyses}

The idea of the viewshed analysis is to place an observer on a digital elevation model (DEM) and determine the visible areas within the terrain under study. The analysis is useful to determine which areas can be seen from one or several places and which areas in the shadow, and cannot be seen (Erdas, 2001, Wheatley, 1995). We executed viewshed analyses by using SRTM DEM (Farr et.al., 2007) with Erdas Imagine 2013 from different heights ranging from $10 \mathrm{~m}, 20 \mathrm{~m}$ and $30 \mathrm{~m}$ predicting the possible heights of the towers. As indicated, least from Palmyra and Hatra we have evidence of towers exceeding $20 \mathrm{~m}$ in height. Satellite image data and SRTM DEM data were fused for producing digital terrain models (DTM).

The visibilities are restricted by hills in Palmyra, Halabiya and the wall itself in Hatra. The radius of the presented circles for viewsheds is $50 \mathrm{~km}$ (Fig. 10.). The background image of the analyses is Landsat-8: channel 7 (2 micrometer central infra), channel 5 (micrometer near infra), channel 2 (blue). The meaning of the colours indicating the viewsheds are following: red indicates what one can see from the height of $10 \mathrm{~m}$, orange from $20 \mathrm{~m}$ and blue from $30 \mathrm{~m}$.

The areas that the viewshed analyses of the tower tombs cover is here presented in $\mathrm{km}^{2}$ in Table 2 .

\begin{tabular}{|l|l|}
\hline Site & $\begin{array}{l}\text { Heights of the towers } \\
10 \mathrm{~m}, 20 \mathrm{~m}, 30 \mathrm{~m}\end{array}$ \\
\hline Palmyra1 & $53.6133,113.5491,166.0542 \mathrm{~km}^{2}$ \\
\hline Palmyra2 & $63.1454,137.2339,270.0591 \mathrm{~km}^{2}$ \\
\hline J.Bishri & $350.0583,393.0313,435.0899 \mathrm{~km}^{2}$ \\
\hline Halabiya & $19.9059,29.0807,35.5363 \mathrm{~km}^{2}$ \\
\hline Hatra & $56.0181,119.7977,201.6446 \mathrm{~km}^{2}$ \\
\hline
\end{tabular}

Table 2.

So, we see that the visibility from the tower tombs of Tabus, if the towers reached the height of $20 \mathrm{~m}$ on Jebel Bishri, can reach very far, over $393 \mathrm{~km}^{2}$, while the tower tombs of Palmyra can reach spatial visibility as far as ca. $113,5-137 \mathrm{~km}^{2}$. This is very logical as the tower tombs of Tabus are at a mountain edge and the visibility is unrestricted and intensive. Hatra reaches a similar distance with the tower tombs of Palmyra. Halabiya, however, reaches less, ca. $29 \mathrm{~km}^{2}$. This indicates that the position of tower tombs of Palmyra in the landscape was most favourable for visibility for observation to a chosen direction. The visibility on Halabiya is very narrow and is limited to the road entering the fortress of Zenobia. The river and the mountain provided natural strategic possibilities, and the road was left to be more intensively surveyed. The analyses show that visibilities seem to have played some role in the function of the tower tombs.
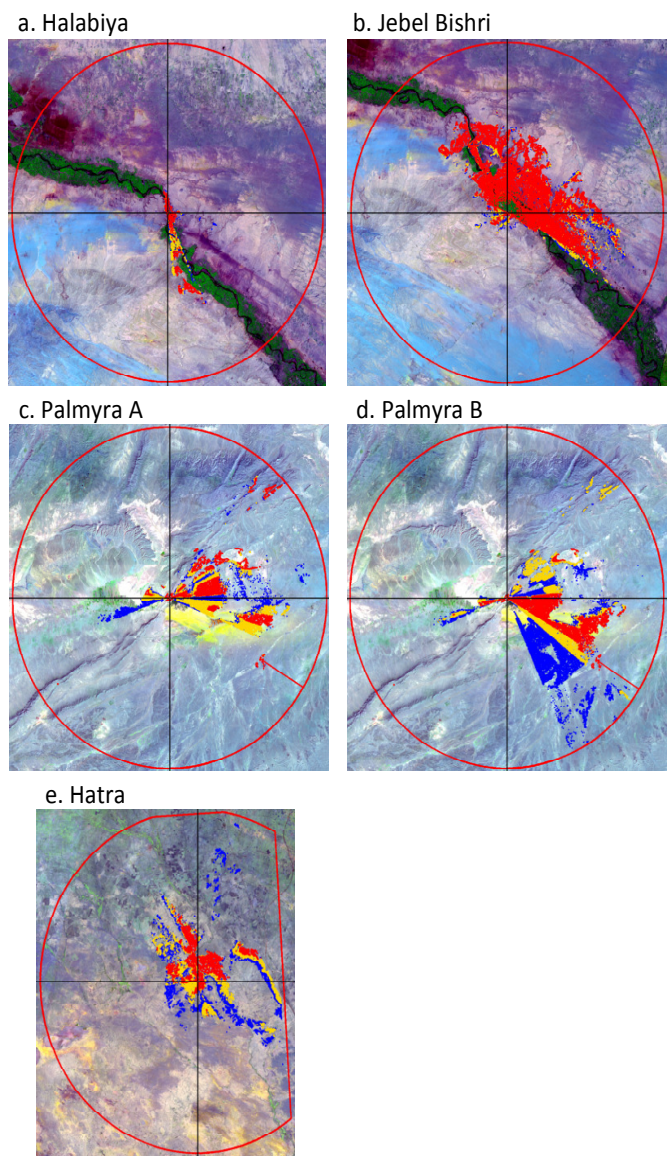

Figure 10.

\section{CONCLUSIONS}

Our study on the tower tombs in the Syro-Mesopotamian sphere has provided some information of the choice of the terrain and location connected with the roads and the entrance areas of the cities. The aspects of the location in terrains are emphasized in the present study, and digital terrain models were utilized using SRTM DEM (Digital Elevation Model) data for carrying out viewshed analyses in order to survey the observational qualities of the towers in Palmyra, on Halabiya, on Jebel Bishri in Syria and Hatra in Iraq.

The high structures of the tombs, their locations and visibilities that they provide along roads and surrounding areas, suggest that beside the funerary function at least some of them seem to have served as observation or look-out points, most likely being used as watchtowers.

The viewshed analyses based on the GIS support the observational qualities of the studied tower tombs. Practical and strategic aspects are understood, when the towers in their locations along the roads and at the entrances of the city area offer observation platforms for following the traffic, like the caravans on the Silk Road. The military aspect for surveillance cannot be dismissed either in the strategic thinking. This is enforced by the existence of such towers in the walls of Hatra which served the strategic purposes for the defence of the city. 
Beside the presented practical and strategic aspects, for the astral religions of the sites the tower tombs may have been functioned not only for funerary rituals but also for stargazing and other rituals connected with celestial beliefs.

The importance to continue to save the information of the cultural heritage and the legacy of Palmyra and Hatra, two World Heritage sites of UNESCO, now at risk in the war zone of Syria and Iraq is finally emphasized in this study.

\section{REFERENCES}

Amy, R. 1950. Temples à Escaliers. Syria, 27, pp. 82-136.

Anadol, S. 2008. Palmyra - Identity Expressed through Architecture and Art. Jebel Bishri in Context, Introduction to the Archaeological Studies and the Neighbourhood of Jebel Bishri in Central Syria. Proceedings of a Nordic Research Training Seminar in Syria, May 2004, ed. by Lönnqvist, M., BAR International Series 1817, Archaeopress, Oxford, pp. 5972 .

Avigad, N. 1976. The Architecture of Jerusalem in the Second Temple Period. Jerusalem Revealed, Archaeology in the Holy City 1968-1974, ed. by Yadin, Y. Israel Exploration Society, Jerusalem.

Brall, A., Breuer, M., Henning, A., Hohbuth, F., Prümm, O., Stamm, T., 2001. Documentation of the Palmyrene TowerTombs in Syria Using Terrestrial Photogrammetry Archaeological and Photogrammetric Results. Proceedings of the XVIII International Symposium CIPA 2001, Surveying and Documentation of Historic Buildings - Monuments -Sites, Traditional and Modern Methods, Potsdam (Germany), September 18-21, 2001, Published by the CIPA 2001 Organising Committee, editor-in-Chief, Prof. Dr.-Ing. Jörg Albertz. The International Archives of Photogrammetry, Remote Sensing and Spatial Information Sciences, Vol. XXXIV, Part 5/C7, pp. 212-217.

Browning, I., 1979. Palmyra. Chatto \& Windus, London.

Dirven, L., 2013. Palmyrenes in Hatra, Evidence for Cultural Relations in the Fertile Crescent. Fifty Years of Polish Excavations in Palmyra 1959-2009, International Conference, Warsaw, 6-8 December 2010, ed. Gawlikowski, M. and Majcherek, M. CENTRUM ARCHOLOGII, Polish Centre of Mediterranean Archaeology, University of Warsaw, pp. 49-60.

Drijvers, H.J.W., 1980. Cults and Beliefs at Edessa. Brill, Leiden.

Edwell, P. M., 2007. Between Rome and Persia: the Middle Euphrates, Mesopotamia and Palmyra under Roman Control. Routledge Monographs in Classical Studies. Routledge, London.

Gawlikowski, M., 1996. Palmyra and its Caravan Trade. Les Annales Archeologiques Arabes Syriennes, Vol. XLII, Special Issue Documenting the Activities of the International Colloquium: Palmyra and the Silk Road, pp. 139-144.

Henning, A., 2013. The Tower Tombs: Chronology, Architecture and Decoration, in Studier Palmyreiskie 12, Fifty Years of Polish Excavations in Palmyra 1959-2009, International Conference, Warsaw, 6-8 December 2010,
CENTRUM ARCHOLOGII, Polish Centre of Mediterranean Archaeology, University of Warsaw, pp. 159-176.

Lönnqvist, M., Lönnqvist, K., Whiting, M.S., Törmä, M., Nuñez, M., Okkonen, J., 2005. Documenting, Identifying and Protecting a Late Roman-Byzantine Fort at Tabus on the Euphrates, in Proceedings of the XX International Symposium CIPA 2005, International Cooperation to Save the World's Cultural Heritage, Turin (Italy) 26 September - 01 October, 2005, Vol. 2, Published by the CIPA 2005 Organising Committee, ed. by Dequal, S. The International Archives of Photogrammetry, Remote Sensing and Spatial Information Sciences, Vol. XXXVI-5/C34, pp. 427-432.

Lönnqvist, M., Törmä, M., Lönnqvist, K., Nuñez, M., 2011. Jebel Bishri in Focus: Remote sensing, archaeological surveying, mapping and GIS studies of Jebel Bishri in Central Syria by the Finnish Project SYGIS, BAR International Series 2230, Archaeopress, Oxford.

Metzger, F.D, 1998. Funerary Buildings at Hatra. Ancient Iran and the Mediterranean World, Proceedings of an international conference in honour of Jozef Wolski held at the Jagiellonian University, Cracow, in September 1996, ELECTRUM, Studia historii starozytney, Studies in Ancient History, ed. by Dabrowa, E., Vol. 2, pp. 45-53.

Poidebard, A., 1934. La trace de Rome dans le désert de Syrie: Le limes de Trajan a la conquête arabe, Recherces aériennes (1925-1932). Bibliothèque Archéologique et Historique. Tome XVIII. Texte. Atlas. Paris: Geuthner

Rostovtzeff, M.,1932. repr. 1971. Caravan Cities. New York: AMS Press.

Rostovtzeff, M., 1937. Rapport sur les fouilles de DouraEuropos, campagne de 1936-1937. Comptes rendus des séances de l'Académie des Inscriptions et Belles-Lettres, Vol. 81, No. 2., pp. 195-204.

Sarre, F. and Herzfeld, E., 1911, 1920. Archäologische Reise in Euphrat- und Tigris-Gebiet. Forschungen zur islamischen Kunst. Reimer.

Seland, E.H., 2008. Trade Routes of Palmyra with Special Notes on Western Routes in the Palmyrene Trade. Jebel Bishri in Context, Introduction to the Archaeological Studies and the Neighbourhood of Jebel Bishri in Central Syria, Proceedings of a Nordic Research Training Seminar in Syria, May 2004, ed. by Lönnqvist, Minna, BAR International Series 1817, Archaeopress, Oxford, pp. 89-97.

Stoneman, R., 1992. Palmyra and its Empire: Zenobia's Revolt against Rome. The University of Michigan Press, Ann Arbor.

Toll, N.P. 1952. The Necropolis. The Excavations at DuraEuropos: $9^{\text {th }}$ season, 1935-1936, part 2. Yale University Press, New Haven.

Wheatley, D., 1995. Cumulative viewshed analysis: a GISbased method for investigating intervisibility, and its archaeological application. Archaeology and Geographic Information Systems, ed. by Lock, G. and Stančič, Z. Taylor \& Francis, London - Bristol, pp. 171-185.

Wheatley, D. and Gillings, M., 2000. Vision, Perception and GIS: developing enriched approaches to the study of 
ISPRS Annals of the Photogrammetry, Remote Sensing and Spatial Information Sciences, Volume II-5/W3, 2015 25th International CIPA Symposium 2015, 31 August - 04 September 2015, Taipei, Taiwan

archaeological visibility. Beyond Map, Archaeology and Spatial Technology Series. Vol. 321, ed. by Lock, G., IOS Press, Amsterdam, pp. 1-27.
Will, E., 1949a. La tour funéraire de Palmyre. Syria, 26, pp. 87116.

Will, E., 1949b. La tour funéraire de la Syrie et les monuments apparentés.
26 ,

pp.

258-312. 